Article

\title{
The Attractiveness of a City-Centre Shopping Environment: Older Consumers' Perspective
}

\author{
Anna-Maija Kohijoki ${ }^{1, *}$ and Katri Koistinen ${ }^{2}$ \\ ${ }^{1}$ Department of Marketing and International Business, Turku School of Economics, University of Turku, 20014 Turku, \\ Finland; E-Mail: anna-maija.kohijoki@utu.fi \\ ${ }^{2}$ Centre for Consumer Society Research, Faculty of Social Sciences, University of Helsinki, 00014 Helsinki, Finland; \\ E-Mail: katri.koistinen@helsinki.fi \\ * Corresponding author
}

Submitted: 16 November 2018 | Accepted: 18 February 2019 | Published: 18 June 2019

\begin{abstract}
Older consumers represent an increasingly significant customer segment for city-centre retailers. However, many intraurban centres are struggling to maintain an attractive shopping environment. This article focuses on older consumers' (Finns, aged 64+) perceptions of the city centre with an emphasis on design and ambient elements in the external shopping environment. Using the focus-group research method, the aim is to identify what kind of elements these are and how they constitute an attractive city-centre shopping environment for older consumers. Findings from a qualitative content analysis show that an attractive city-centre shopping environment provides convenience and safety when moving around and running errands, functional and aesthetic lighting to cope with shopping, proper furnishings regarding places to rest, harmonious building architecture integrated with refreshing urban nature, and the cleanliness of the streetscape. Findings indicate that a city-centre shopping environment offers more to older consumers than a context of satisfying consumption needs. City shopping gives a reason to go outdoors and maintain social contacts. The study has implications for creating an age-friendly city centre, the shopping environment which supports older consumers' active and independent lives.
\end{abstract}

\section{Keywords}

attractive city; city centre; external shopping environment; older consumer; perception

Issue

This article is part of the issue "The City, Aging and Urban Planning", edited by Matthias Drilling (University of Applied Sciences and Arts Northwestern Switzerland) and Fabian Neuhaus (University of Calgary, Canada).

(C) 2019 by the authors; licensee Cogitatio (Lisbon, Portugal). This article is licensed under a Creative Commons Attribution 4.0 International License (CC BY).

\section{Introduction}

The declining vitality in many Western city centres has become a burning issue. The increased competition from off-centre retailing and e-commerce has put pressure on intra-urban centres to maintain their attractiveness as shopping environments (e.g., Parker, Ntounis, Millington, Quin, \& Castillo-Villar, 2017; Wrigley \& Lambiri, 2015). To stay vital, city centres need to exhibit adaptive resilience by providing a differentiated offer and physical characteristics compared to its competitors (Teller, Wood, \& Floh, 2016). As a reaction, urban-development projects have been implemented, aimed at improving the functionality and aesthetics of the city centre (De Nisco \& Warnaby, 2014). As there is evidence that the physical environment influences patronage behaviour (e.g., Donovan \& Rossiter, 1982; Teller \& Reutterer, 2008; Turley \& Milliman, 2000), in urban-revitalisation projects, more emphasis should put on consumers' perceptions of the shopping environment (De Nisco \& Warnaby, 2013; Hart, Stachow, \& Cadogan, 2013).

Population ageing should also be taken into account in urban-development projects with regards to catering to the increasing number of older shoppers. By the year 2030, the old-age dependency ratio (the number of $64+$ people vs the number of 15 - to 64 -year-olds) in 
the EU has been estimated to rise from the current $29 \%$ to $39 \%$ (Eurostat Database, 2018). Although city centres are essential destinations for older shoppers (Bromley \& Thomas, 2002; Wrigley \& Lambiri, 2015), their perceptions have been overlooked, the emphasis being on younger consumers. Contrary to recent evidence, older consumers have been considered as a homogeneous group outside the mainstream consumption (Kohijoki \& Marjanen, 2013; Myers \& Lumbers, 2008). To create an age-friendly shopping environment, Western cities will have to adjust to the diverse needs and wants of their ageing customers (Buffel, Phillipson, \& Scharf, 2012).

This study focuses on older consumers' (aged 64+) perceptions of the city centre as a shopping environment. Based on the typologies of the retail environment elements (e.g., Baker, 1986; De Nisco \& Warnaby, 2013), the study contributes to current knowledge by focusing on the tangible elements in the external shopping environment. It has been shown that the physical environment plays a major role in enabling older consumers to cope with their shopping (Buffel et al., 2012; Kohijoki, 2011). However, the retail-oriented outdoor space has not gained as much attention in consumer-related research as the internal store environment (e.g., Hart et al., 2013). Through qualitative content analysis of the focusgroup discussions, the study explores the contents and meanings of older consumers' perceptions related to the design (functional and aesthetic) and ambient (i.e., atmospherics) elements in the city-centre shopping environment. The aim is to identify what kind of elements these are and how they constitute an attractive city-centre shopping environment for older consumers. The study deepens the understanding of older city shoppers and endeavours to find the means to create an age-friendly city centre that caters to older consumers' needs and pro- vides shopping experiences which differ positively from those in competing retail environments.

\section{Effect of the Physical Shopping Environment on Consumers}

A physical shopping environment (see Figure 1) comprises the internal store environment and the external shopping environment (e.g., shopping streets and markets), with a vaguely bordered transitional zone (e.g., street terraces) (Baker, 1986; Underhill, 1999). Both environments constitute the tangible and intangible elements, which have been found to influence consumers' perceptions. The tangibles include ambient elements such as sounds and lighting, and design elements including layout, convenience (e.g., moving around, wayfinding) and architecture (Baker, Grewal, \& Parasuraman, 1994; De Nisco \& Warnaby, 2013). Tangibles provide the physical context of the intangibles, which refer to the social interaction within the environment (Bitner, 1992; Hart et al., 2013). Being measurable, observable, or manufactured, tangibles offer concrete means to enhance the attractiveness of the shopping environment (Baker, 1986; Rosenbaum \& Massiah, 2011).

The influence of environmental elements in consumers' perceptions of a store has been widely recognised (e.g., Baker et al., 1994; Teller \& Reutterer, 2008; Turley \& Milliman, 2000), and retailers have aimed at controlling the internal elements, background music, for instance, to increase overall attractiveness or target the customer segment they prefer (willingness to linger/revisit). The external elements have not gained as much attention in retailing research (De Nisco \& Warnaby, 2013). It has been argued that consumers' perceptions are much difficult to understand and control

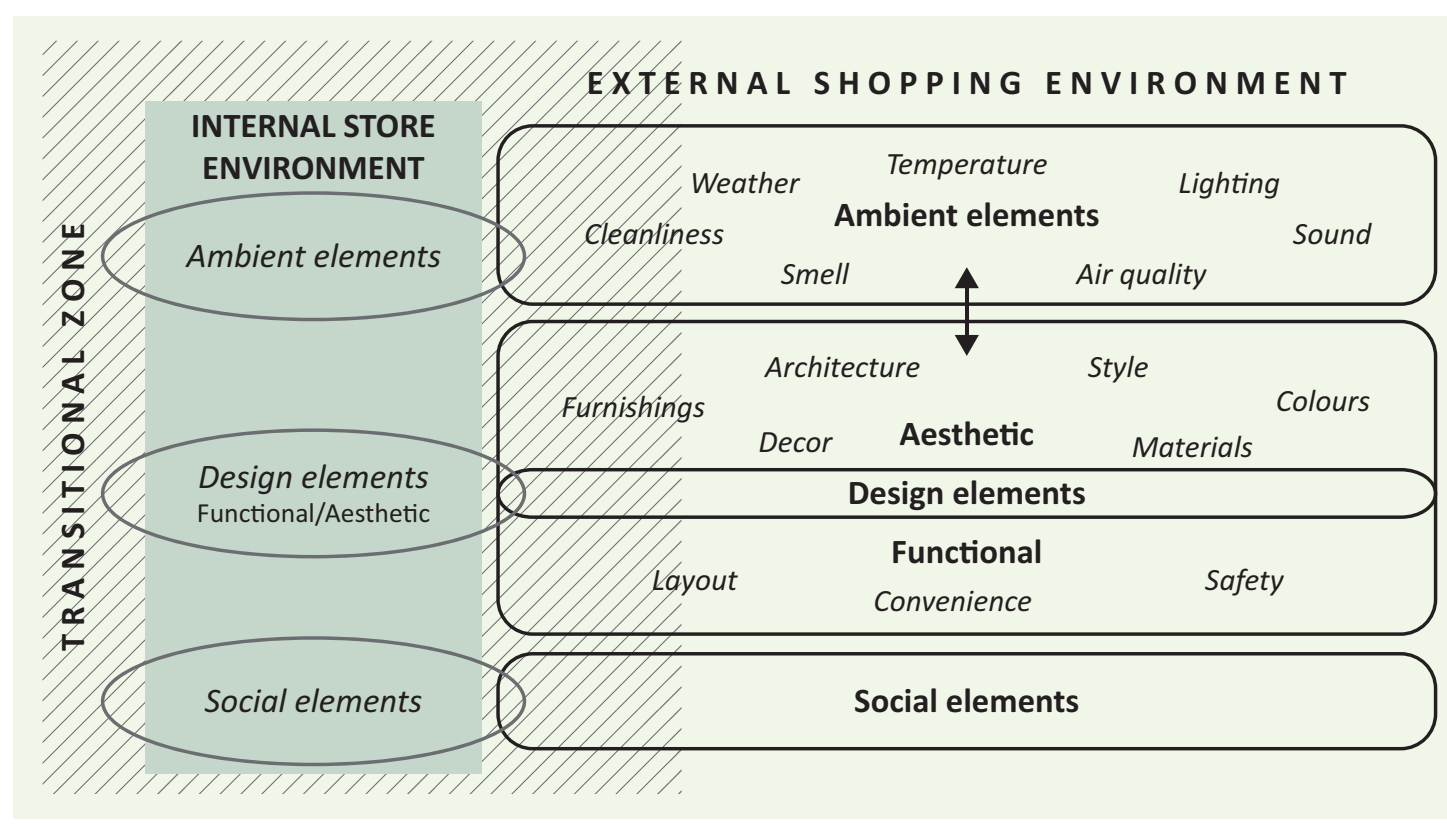

Figure 1. The external elements in the physical shopping environment. 
in evolved shopping environments, such as city centres, than in a created store environment (Hart et al., 2013). The externals are usually beyond the direct control of retailers. In recent years, however, generated by the public-private collaborated urban-development projects, academic studies on the external shopping environment have increased (e.g., De Nisco \& Warnaby, 2013, 2014; Hart et al., 2013; Parker et al., 2017).

Several typologies of the retail environment elements have been constructed to analyse the effect of the physical shopping environment on consumers in a store and its immediate exterior (e.g., Baker, 1986; Bitner, 1992; Turley \& Milliman, 2000). Recently, these typologies have been applied in the external shopping environment (e.g., De Nisco \& Warnaby, 2013; Hart et al., 2013). The framework presented in Figure 1 is outlined based on the review of retailing literature (Kohijoki \& Koistinen, 2018) to illustrate these somewhat overlapping typologies of ambient, design, and social elements and to specify the external, tangible elements that have been found to influence consumers.

The ambient elements, which have an effect on consumers' sensations, have been found to influence shopping enjoyment (Hart et al., 2013; Teller, 2008). Interesting sounds and smells, and a clean inner-city environment, for instance, are particularly attractive to consumers with experiential shopping motives (Dawson, Bloch, \& Ridgway, 1990). Although occasionally unpleasant, the temperature, the air and smells, do not seem to have a significant effect on re-visiting or time spent in the shopping environment (Teller \& Reutterer, 2008). However, poor weather is among the most frequently mentioned reasons for shopping indoors (Dellaert, Arentze, \& Timmermans, 2008). Although the typologies separate ambient from design elements (e.g., Hart et al., 2013; see Figure 1), there is a link between them in that design elements can be used to control the ambience, and vice versa (e.g., the effect of lighting on safety).

The design elements have been further divided into aesthetic and functional elements (e.g., Baker, 1986; De Nisco \& Warnaby, 2013; see Figure 1). Aesthetic design elements have been found to be an asset of a competitive intra-urban centre (Wrigley \& Lambiri, 2015). The attractiveness of the buildings and store window displays (including architecture, style, colours, and decors) affect the consumers' willingness to stay and patronise (Bell, 1999; De Nisco \& Warnaby, 2013). A visually appealing environment is particularly attractive to recreational shoppers who like to spend time in the shopping area (Reimers \& Clulow, 2014). A functional urban layout (space arrangement) and convenience of moving around, parking, and use of public transportation have also appeared to influence patronage intentions and the willingness to linger (e.g., De Nisco \& Warnaby, 2013; Wrigley \& Lambiri, 2015). However, a cityscape with several vacant stores may arouse feelings of insecurity, in the evening in particular (Maronick, 2007; Wrigley \& Lambiri, 2015). Although presented separately, the aesthetic and func- tional design elements overlap as some elements may have both functional and aesthetic effects (e.g., the effect of street surfacing on convenience).

These examples of the external elements are compiled from a variety of retailing studies conducted mostly quantitatively in Western societies (Europe, USA, and Australia) over the past decades (see Kohijoki \& Koistinen, 2018). To get a deeper insight into the external elements, the qualitative approach should be utilised to identify what kind of elements these are and how they make the city centre attractive to present-day consumers. As the elements may be interconnected (see Figure 1), and as there may be contextual differences in perceptions (location, scale, time), elements should be investigated in one city centre. Attention should also be given to different consumer groups instead of "average" consumers.

There is a need for understanding the behaviour and perceptions of older city shoppers, the number of which is increasing. The functionality of the outdoor environment as a significant determinant of an age-friendly city has gained attention in ageing-related studies (e.g., Buffel et al., 2012). It has emphasised that physical obstacles in the pedestrian environment may decrease the potential of older people to engage in activities outside the home (Hovbrandt, Ståhl, Iwarsson, Horstmann, \& Carlsson, 2007; Hunter et al., 2011). Older people's relationships with the shopping environment have gained increasing attention in consumer-related research, mostly considering the store environments. Findings on the external shopping environment have emphasised the effect of consumer ageing on the accessibility of services. Where city centres decline, older consumers, the carless, and the disabled in particular, have become disadvantaged with respect to their possibilities to access adequate services (Bromley \& Thomas, 2002; Kohijoki, 2011). These examples show that the physical environment has a fundamental role in supporting older consumers to take care of their shopping independently. However, besides the functional elements, more emphasis should be placed on the aesthetics and ambience of the external shopping environment. It has been shown that in their shopping destination choices, older consumers have become increasingly recreational shoppers who appreciate not only barrier-free but also pleasant and stimulating shopping surroundings (Kohijoki \& Marjanen, 2013; Myers \& Lumbers, 2008). The current study stresses the importance of listening to older consumers and taking their thoughts into consideration in retail and urban planning to create an age-friendly city-centre shopping environment that caters to older city shoppers.

\section{Methods}

\subsection{Research Area and Focus-Group Approach}

The study was conducted in the city of Turku, which is the administrative and commercial centre of the third 
largest urban region (population 325,000) in Finland. The old-age dependency ratio in the Turku region (32\%) was higher than in other large urban regions, Tampere (30\%) and Helsinki (25\%), and it has been estimated to rise to $39 \%$ by 2030 (Official Statistics of Finland, 2018). Similar to many Western cities, the declining vitality of the Turku city centre has generated several urban-development projects (City of Turku, 2014).

The focus-group approach was chosen to collect indepth information on city-centre shopping environment from older consumers' perspective. The method did not discriminate against people who were unable to fill in questionnaires (declining eyesight, hand disabilities) or who were not accustomed to using information technology. In a web-based survey conducted by the Turku city centre (Laukkanen, 2016), for example, the proportion of $64+$ respondents (2\%) was much lower than their actual share (19\%) of the citizenship. Focus groups also encouraged those who were reluctant to be interviewed on their own to participate (Kitzinger, 1995). Having participants at a similar stage of life, like old-age pensioners in this study, also made it easier for them to discuss agespecific challenges, for example.

\subsection{Recruitment of the Focus-Group Participants}

In line with the recommended number and size of the groups (Krueger, 1988; Morgan, 1997), four focus-group discussions with 5 to 6 participants (a total of 2 men and 20 women) were organised in the autumn of 2016 (see Table 1). The participants were recruited on a volunteer basis through senior clubs, housing corporations, and the authors' networks. The authors had contact persons (member/host of a circle of friends/club/residence) who were guided to compile the groups, consisting of both men and women, from the communities they represented. The contact persons were informed of the predefined criteria for the volunteers to be accepted. Given the purpose of the study, the participants had to be aged $64+$, live and do their shopping independently, and be familiar with the Turku city centre. However, they did not have to be frequent shoppers to get insights into the avoidance. Before the discussions, the authors ensured that these homogeneity criteria were met. Otherwise, the participants differed regarding background, which gave the desired variation among the participants to allow for contrasting views (cf. Krueger, 1988). However, it was easier to get women more involved in the discussions than men; two men even cancelled at the last minute. Regarding the ethicality, this research design did not include such interaction with the participants that would have required permission from the Ethics Committee of the University of Turku (2018).

\subsection{Focus-Group Discussions}

Both authors facilitated the discussions (average length of two hours): one was the moderator, and the other

Table 1. Background information on the focus-group participants.

\begin{tabular}{|c|c|c|c|c|c|c|c|}
\hline $\begin{array}{l}\text { Participants' } \\
\text { relationship } \\
\text { to each other }\end{array}$ & $\begin{array}{l}\text { Venue of } \\
\text { the session }\end{array}$ & Gender & $\begin{array}{l}\text { Year of } \\
\text { birth }\end{array}$ & $\begin{array}{l}\text { Household } \\
\text { size }\end{array}$ & $\begin{array}{l}\text { In/off-centre } \\
\text { resident }\end{array}$ & $\begin{array}{l}\text { House type } \\
\text { (based on address) }\end{array}$ & $\begin{array}{l}\text { Access } \\
\text { to a car }\end{array}$ \\
\hline $\begin{array}{l}\text { Friends who } \\
\text { meet regularly }\end{array}$ & $\begin{array}{l}\text { Private } \\
\text { apartment; } \\
\text { Kaarina } \\
\text { (next town } \\
\text { to Turku) }\end{array}$ & $\begin{array}{l}\text { Woman } \\
\text { Woman } \\
\text { Woman } \\
\text { Woman } \\
\text { Woman }\end{array}$ & $\begin{array}{l}1952 \\
1950 \\
1949(A) \\
1948(A) \\
1948(B)\end{array}$ & $\begin{array}{l}\text { one } \\
\text { two } \\
\text { one } \\
\text { two } \\
\text { one }\end{array}$ & $\begin{array}{l}\text { off-centre } \\
\text { off-centre } \\
\text { off-centre } \\
\text { in-centre } \\
\text { off-centre }\end{array}$ & $\begin{array}{l}\text { apartment } \\
\text { apartment } \\
\text { detached } \\
\text { apartment } \\
\text { apartment }\end{array}$ & $\begin{array}{l}\text { yes } \\
\text { yes } \\
\text { yes } \\
\text { yes } \\
\text { no }\end{array}$ \\
\hline $\begin{array}{l}\text { Members of a } \\
\text { senior citizens' } \\
\text { club }\end{array}$ & $\begin{array}{l}\text { Club } \\
\text { premises; } \\
\text { Turku }\end{array}$ & $\begin{array}{l}\text { Woman } \\
\text { Woman } \\
\text { Woman } \\
\text { Woman } \\
\text { Woman } \\
\text { Woman }\end{array}$ & $\begin{array}{l}1949(B) \\
1946 \\
1944(A) \\
1938 \\
1937 \\
1935(A)\end{array}$ & $\begin{array}{l}\text { two } \\
\text { one } \\
\text { two } \\
\text { one } \\
\text { one } \\
\text { one }\end{array}$ & $\begin{array}{l}\text { off-centre } \\
\text { in-centre } \\
\text { off-centre } \\
\text { off-centre } \\
\text { in-centre } \\
\text { in-centre }\end{array}$ & $\begin{array}{l}\text { detached } \\
\text { apartment } \\
\text { terraced } \\
\text { apartment } \\
\text { apartment } \\
\text { apartment }\end{array}$ & $\begin{array}{l}\text { yes } \\
\text { yes } \\
\text { yes } \\
\text { no } \\
\text { yes } \\
\text { no }\end{array}$ \\
\hline $\begin{array}{l}\text { Members of a } \\
\text { citizens' club }\end{array}$ & $\begin{array}{l}\text { University } \\
\text { premises, } \\
\text { Turku }\end{array}$ & $\begin{array}{l}\text { Woman } \\
\text { Woman } \\
\text { Woman } \\
\text { Man } \\
\text { Woman }\end{array}$ & $\begin{array}{l}1951 \\
1945 \\
1944(B) \\
1944 \\
1936\end{array}$ & $\begin{array}{l}\text { two } \\
\text { two } \\
\text { two } \\
\text { two } \\
\text { two }\end{array}$ & $\begin{array}{l}\text { off-centre } \\
\text { off-centre } \\
\text { off-centre } \\
\text { off-centre } \\
\text { off-centre }\end{array}$ & $\begin{array}{l}\text { detached } \\
\text { apartment } \\
\text { terraced } \\
\text { terraced } \\
\text { apartment }\end{array}$ & $\begin{array}{l}\text { yes } \\
\text { yes } \\
\text { yes } \\
\text { yes } \\
\text { yes }\end{array}$ \\
\hline $\begin{array}{l}\text { Residents of } \\
\text { a housing } \\
\text { corporation }\end{array}$ & $\begin{array}{l}\text { Housing- } \\
\text { corporation } \\
\text { premises, } \\
\text { Turku }\end{array}$ & $\begin{array}{l}\text { Man } \\
\text { Woman } \\
\text { Woman } \\
\text { Woman } \\
\text { Woman } \\
\text { Woman }\end{array}$ & $\begin{array}{l}1943 \\
1935(\mathrm{~B}) \\
1934 \\
1932 \\
1923 \\
1922\end{array}$ & $\begin{array}{l}\text { two } \\
\text { one } \\
\text { one } \\
\text { one } \\
\text { one } \\
\text { one }\end{array}$ & $\begin{array}{l}\text { in-centre } \\
\text { in-centre } \\
\text { in-centre } \\
\text { in-centre } \\
\text { in-centre } \\
\text { in-centre }\end{array}$ & $\begin{array}{l}\text { apartment } \\
\text { apartment } \\
\text { apartment } \\
\text { apartment } \\
\text { apartment } \\
\text { apartment }\end{array}$ & $\begin{array}{l}\text { yes } \\
\text { no } \\
\text { no } \\
\text { no } \\
\text { no } \\
\text { no }\end{array}$ \\
\hline
\end{tabular}


made notes and ensured the recording. At the beginning of the discussions, the moderator described the purpose of the study, emphasised its confidentiality, and provided guidelines for the discussions. The discussions followed pre-formulated themes (see Table 2). After the short round of introductions, the participants described their typical shopping trip to the city centre and discussed how they are currently catered for. In the main section, participants gave their first impressions of the physical appearance of the city centre, and after that, the literature-based external elements (see Figure 1) were discussed one at a time. In addition to the current state, the proposals for improvements were discussed. After the free discussion, the participants filled in a brief questionnaire (font size larger than normal) of their background information (see Table 1). Overall, the discussions were successful. The participants discussed actively and raised issues spontaneously. The participants were pleased that the researchers and the city authorities are interested in their perceptions.

\subsection{Analysis}

The discussions were transcribed, and prior to the analysis, the identity of the participants was anonymised to maintain research confidentiality. The data were analysed by qualitative content analysis complying with deductive logic (e.g., Mayring, 2004; Tuomi \& Sarajärvi, 2018). After thorough readings of the transcripts, the comments and proposals for improvements of the participants were systematically organised according to the external elements in the theoretical framework (Figure 1), and the contents and meaning of the comments were analysed. The comments were further divided in two concerning the positive/pleasant perceptions (attractiveness) and the negative/unpleasant perceptions (unattractiveness), respectively. This theorybased analysis continued with the composing of the summaries of the perceptions with respect to each element (cf. Krueger, 1988; Mayring, 2004). In this arti- cle, the participants' background information and typical shopping trip are described first, and then the summaries of the element-related perceptions and proposals are presented.

\section{Findings}

\subsection{Focus-Group Participants}

\subsubsection{Background}

The participants were 64 to 94 years old (the mean age 75) pensioners. Over half of them lived alone (see Table 1), which corresponded with the 64+ households in the Turku area (one-person households: 57\%; cf. Official Statistics of Finland, 2018). Similar to the local level (70\%), the majority of the participants, mostly incentre residents, lived in apartments. All participants lived within eight kilometres of the Market Place, which they considered to be the heart of the city-centre shopping environment (Figures 2 to 4 ). Most of the participants had access to a car, which corresponds to the $64+$ drivers in Finland (68\%; Official Statistics of Finland, 2018). There is no upper age limit for holding a driving licence, but after the age of 70 , a medical certificate is required (renewable regularly). It came out that many had functional limitations, but for now, only a couple of them needed assistive devices (e.g., a walking stick). Two participants had a disabled parking permit.

\subsubsection{Typical Shopping Trip to the City Centre}

Several modes of travel (walking, cycling, driving, and taking a taxi) were used, the bus being the most likely choice. In addition to the Market Place, popular shopping destinations included department stores, the Market Hall, and the Riverfront Promenade (see Figures 3 and 4). For a handful of participants, mostly in-centre residents, city shopping was a pleasant everyday activity whereas the majority did city shopping on a weekly basis. Visiting

Table 2. The pre-formulated themes of the focus-group discussions.

\begin{tabular}{|c|c|}
\hline Introduction & $\begin{array}{l}\text { - Introduce yourself briefly and tell the group where you usually buy your groceries and why you } \\
\text { shop in that particular place. }\end{array}$ \\
\hline $\begin{array}{l}\text { A typical shopping } \\
\text { trip to Turku } \\
\text { city centre }\end{array}$ & $\begin{array}{l}\text { - What comes to mind first when you think about Turku city centre as a shopping environment? } \\
\text { - Describe your typical shopping trip to Turku city centre. } \\
\text { - How are older consumers catered to in Turku city centre? }\end{array}$ \\
\hline $\begin{array}{l}\text { Turku city } \\
\text { centre as } \\
\text { a physical } \\
\text { shopping } \\
\text { environment }\end{array}$ & $\begin{array}{l}\text { - Describe how you perceive the physical appearance of Turku city centre. } \\
\text { - What thoughts does this design element arouse when you consider Turku city centre, and what } \\
\text { thoughts does it arouse if you think about developing the city centre? } \\
\text { - What thoughts does this ambient element arouse when you consider Turku city centre, and what } \\
\text { thoughts does it arouse you think about developing the city centre? }\end{array}$ \\
\hline Free discussion & - Is there anything else you would like to share with us about the topic? \\
\hline
\end{tabular}

Notes: design elements: layout, convenience, safety; architecture, style, colours, materials, furnishings, décor; ambient elements: weather, temperature, air quality, smell, lighting, sounds, cleanliness. 


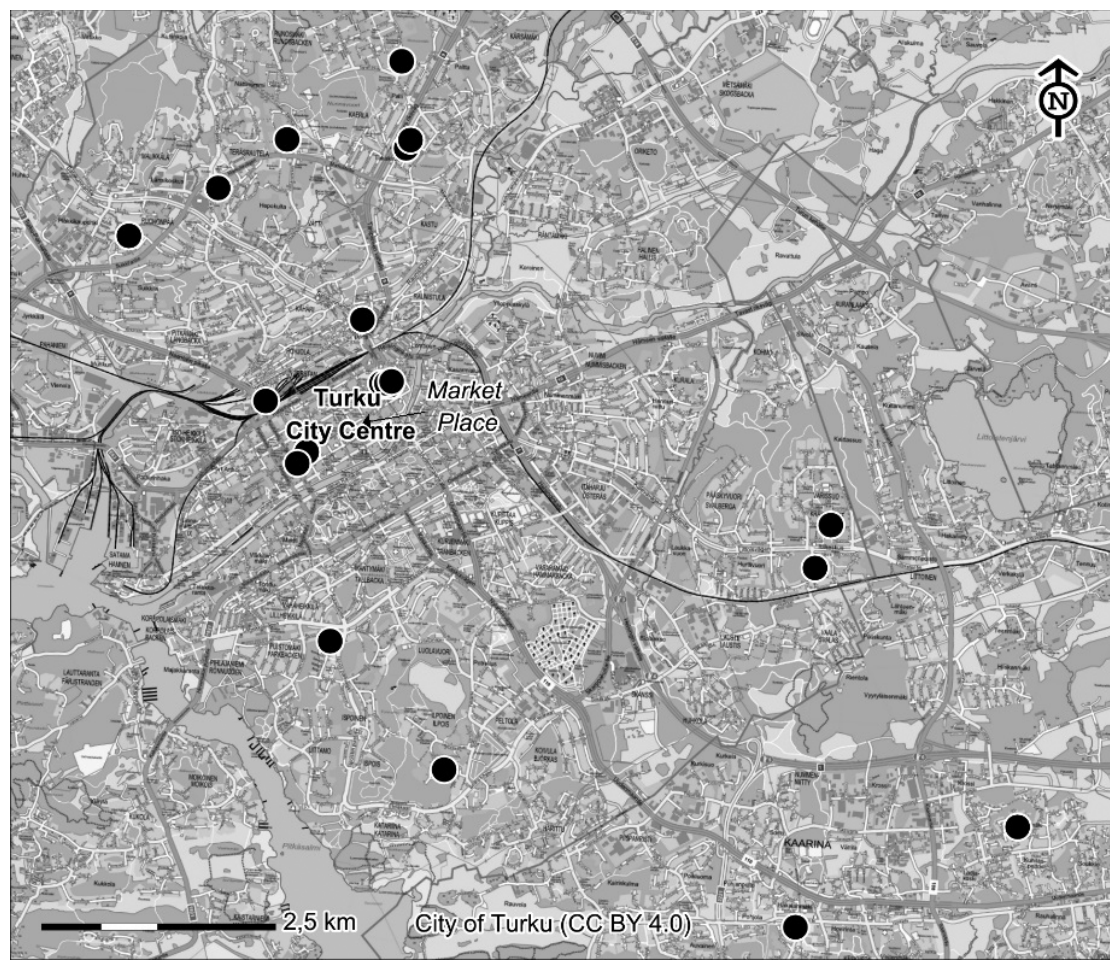

Figure 2. The focus-group participants' place of residence with respect to the city centre.

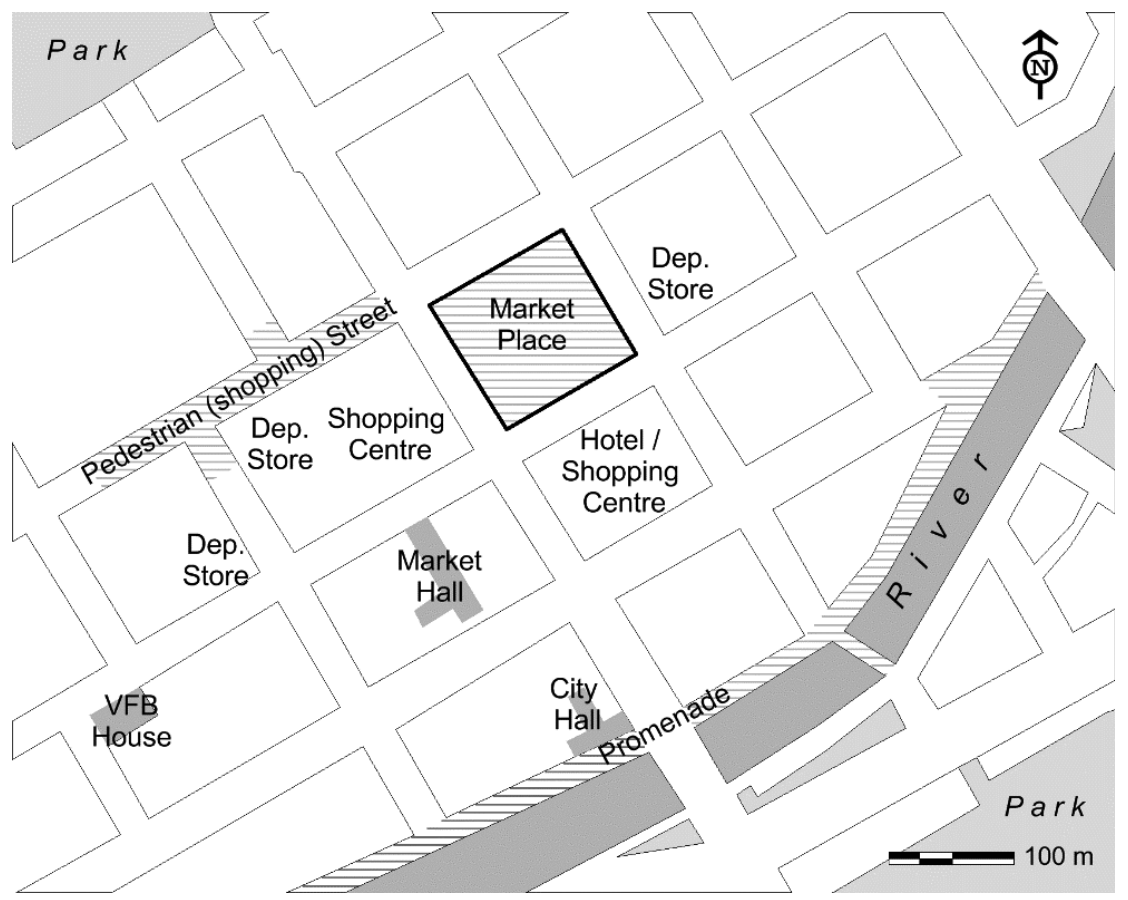

Figure 3. The Turku city-centre shopping environment with places of interest.

cafes or restaurants and meeting other people was important to these recreational shoppers. There were also a few infrequent city shoppers, who did not want to spend extra time in the centre. However, they argued that they would connect shopping with other activities if the physical environment were more attractive.

Common to all participants, a reason for city shopping was the access to services that could not be ac- quired elsewhere. Although there was a desire for clothing stores targeted at older adults, participants agreed that the city centre catered to them considerably well. In this context, attitudes toward other shopping environments were raised. The out-of-town shopping centres were thought to be targeted at younger shoppers. However, hypermarkets were popular among the off-centre residents due to the convenience in parking. Although 

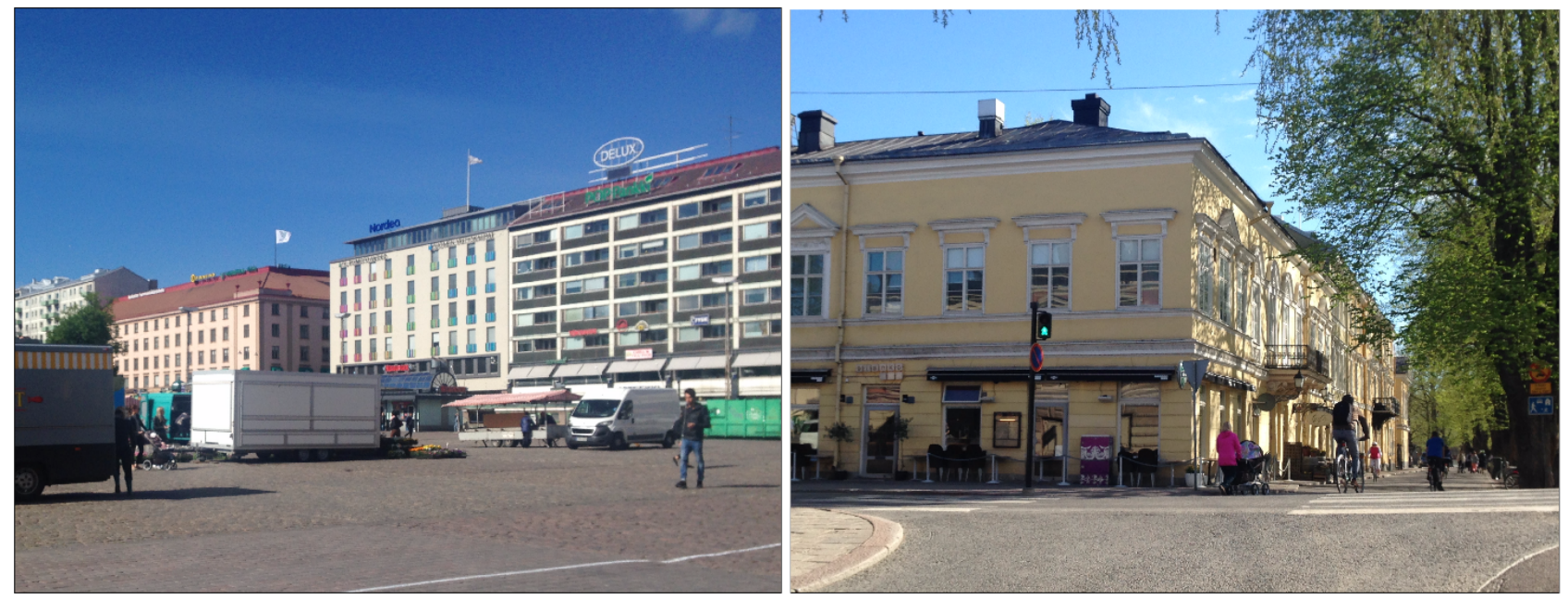

Figure 4. The Market Place (left) and the Riverfront Promenade (right).

the majority had sufficient know-how to use e-services, e-shopping was seen as a socially isolating and physically weakening activity. Participants wished to stay healthy and capable of moving in order to be able to take care of their shopping independently for as long as possible:

It's important to us...that we can go where we want by ourselves... [that] we can go to the library...we can buy potatoes...by ourselves....This kind of activity is decreasing; it's highly valuable to maintain this option. (Woman, 82)

The first impressions of the city centre were mainly related to building architecture and style, outdoor furnishing, the convenience of street surfacing and parking, and the cleanliness of the streetscape. In their first impressions, participants used generic words to describe the environment, such as "easy", "difficult", "beautiful", "bland", or "annoying". When the shopping environment was discussed element by element, participants were able to open up their thoughts; what kinds of elements constitute "a beautiful building", for example.

\subsection{Functional Design Elements: Convenience, Layout and Safety}

Convenience provoked heated discussions from different perspectives. Regarding accessibility, there was a consensus that the city centre was more convenient to access by bus than by car. The sustainable aspect of transportation was not emphasised. The low-priced senior travel card, terminal points located around the Market Place, and parking inconvenience made the participants travel by bus. However, the downside of travelling by bus was that it restricted purchasing to light (if any) items. Thus, when making heavy purchases, the off-centre residents, in particular, drove to out-of-centre stores: "If I need a lot of groceries, I'll go to that [hypermarket] because I can park inside....Pushing the trolleys outside in other places is difficult" (Woman A, 67). As this was not an option for carless shoppers, who were dependent on outside help (e.g., taking a taxi), the ticket scanners were suggested to be installed near the wide back doors on buses to make it easier for mobility-impaired shoppers to travel with bags. It was considered unfair that only those who are permitted to travel free (wheelchair users, passengers with prams) may use the back doors.

The convenience of parking evoked several viewpoints. The participants agreed that enough parking facilities were available. However, those who preferred driving argued that the short-term and high-charge parking prevent them from spending as much time as they would like in the city centre. Participants were sceptical about the planned underground parking in the Market Place, not only because of the high charges but also because of the inconvenience of parking halls in general: "The [parking] times are so short that I take my car to a parking hall, but it's complicated due to my disability" (Woman, 64). As the walking distance to the car increases if the purchases have to be carried underground, those with a disabled parking permit were pleased that they have been allowed to park above ground: "I can visit many stores; it's easy to take purchases there [around the Market Hall and the City Hall] so that I don't have to carry them all at once" (Woman A, 67). To decrease the inconvenience of parking, the participants hoped for reasonable pricing and new spacious places available for all senior drivers at the street level.

The convenience of moving around raised various perceptions as it was closely connected to layout and safety. It was repeated that the grid street plan layout (see Figure 3) made it easier to perceive the location of the places and navigate among them: "The streets are...long and straight. As it's so small and compact, it's easy to run errands and go from one place to another" (Woman B, 81). The city centre, the Riverfront Promenade, in particular, was perceived as a barrier-free, thus safe environment to walk around. However, some histor- 
ical storefronts (e.g., stairs without ramps/railings) and pedestrian areas (e.g., high kerbs, uneven pavements) required investment.

In addition to convenience, safety was related to social interaction within the environment. None of the participants had been subjected to personal violence. However, the fear of being harassed meant that they avoided late shopping (some stores are open until 9 p.m.). Even though they preferred daytime shopping during off-peak hours, participants felt insecure when walking among the traffic. However, they did not support the City's plans for banning private cars around the Market Place as they wished to be able to drive to the centre by themselves. The traffic also seemed to strengthen their feeling of security: if something happens, help is at hand. By "something" they referred to a high risk for older shoppers of falling over or slipping on the street: "It's uneven and when frost sets in and it's slippery...older people fall over" (Woman, 65). The proposals considered to increase convenience and safety were all-year street maintenance and proper lighting at dusk.

\subsection{Aesthetic Design Elements}

\subsubsection{Architecture, Style, and Colours}

The architecture and style of the city centre provoked lively discussion. The shopping environment was considered visually attractive, although it was criticised for lacking a consistent architectural line: "Not by the riverside, elsewhere, there's one splendid building here and there" (Man, 73). Prefabricated buildings, mainly from the 1960s and 1970s, were perceived as ruining the cityscape with its beautiful neoclassical/renaissancestyled buildings.

Perceptions of colours were closely related to architecture. The first impression was a greyness of concrete buildings, which was interesting given that there were very few unpainted concrete surfaces. When participants described what made historical buildings beautiful, the architecture, colours, and ornamentation were emphasised. The pleasant colour palette included yellow walls and detailing in white (Figures 4 and 5). Regarding landscape architecture, green parks, trees glowing with autumn tints or snow white and multi-coloured beds of flowers evoked positive sensations: "This is a city of maples. In the autumn, it's a work of art" (Woman, 80). Noteworthy, a touch of nature while shopping was considered to be vital for those who were unable to come in contact with nature and walk outside the centre. The importance of respecting historical buildings and conserving the parks and trees when implementing urbandevelopment projects was stressed.

\subsubsection{Materials}

In terms of materials, the participants repeated their perceptions related to the architecture, convenience, and safety. In general, natural materials (stones, trees, plants, and water) were perceived as enriching the urban environment. Although some participants approved of cobbled streets as part of the medieval architecture, cobblestone was perceived as a non-functional material due to the unevenness and slipperiness: "The surfacing of the Market Place annoys me...even me, a healthy person, when I'm carrying shopping bags my eyes are focused on the ground, you cannot concentrate on the environment" (Woman, 82). It was proposed that there should also be smooth walkways in cobbled areas. In addition, an understreet heating system, similar to the Pedestrian Street, should be installed whenever it is possible.

\subsubsection{Furnishings and Décor}

Regarding urban furnishings, the limited provision of public seating and rubbish bins was emphasised. Although participants were pleased that the number of street terraces had increased in recent years (e.g., the Pedestrian Street, the Riverfront), they did not always want to be obligated to buy a cup of coffee when they needed to sit. They demanded proper and clean public seating for resting and enjoying the cityscape while shopping: "There should be benches in the Market Place...I think that our mobility is worsening all the time" (Woman B, 68).

As participants argued, to avoid falling full-length on the street they could not look upwards, the décor did not immediately evoke discussion. After thinking for a while, they mentioned flowers, statues, doors, iron gates, and murals. Those inclined towards recreational shopping desired more street art, such as the professionally made graffiti to embellish the dull, concrete walls (Figure 5): "I see them as the decorators or creators of the cityscape" (Woman A, 68). It was also suggested that bland rubbish bins be decorated with artwork would make the environment more attractive, and cleaner. It is noteworthy that the shop windows were considered the decors of the shopping environment. As a hint to brickand-mortar retailers, windows covered with modern advertising posters were perceived to be as boring as vacant stores.

\subsection{Ambient Elements}

\subsubsection{Weather and Temperature}

Despite seasonal differences, the climate did not affect city-centre patronage very much, but it influenced convenience and safety. The participants visited the city centre all year round: "I visit the Market Place whether it's winter or summer, the weather has no effect on that" (Woman B, 67). However, when the streets were icy or slushy, they faced challenges. In intolerable weather, some participants drove to out-of-town hypermarkets, but the carless, mobility-impaired occasionally felt trapped in their homes: "The winter isolates all of us 


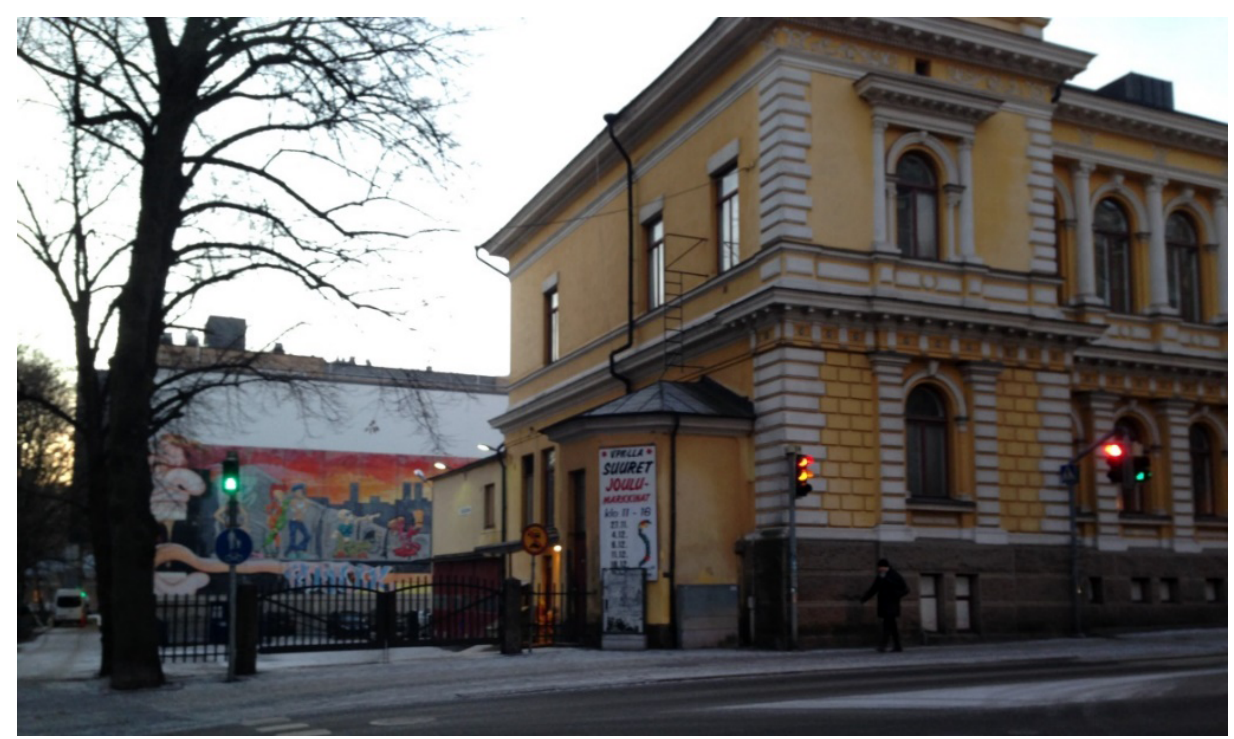

Figure 5. The old building (the VFB House) and iron gate against a contemporary mural.

crippled people" (Woman, 82). The temperature in itself was not an issue: it was just a matter of clothing. Worth noting, recent winters in the area have been less-snowy (Figure 5), which has not prevented outdoor activity. However, the under-street heating system was brought up again as a means to increase shopping enjoyment.

\subsubsection{Air Quality, Smell, and Sounds}

The airborne elements did not arouse heated discussion, but it was noticed that air quality and smells were much better inside than outside the centre: "I don't think we have such bad smell in the centre as they do in some other places in the city" (Woman A, 68). However, a few occasional sources of unpleasantness came up: stinking rubbish bins and cigarette smoke in the storefronts, street dust in the spring, and the winter inversion that traps pollution at the street level. The pleasantness includes aromas coming from street terraces, the scent of flowers, and "fresh air which comes nicely from the sea" (Man, 72).

Although the hubbub of traffic was perceived as unpleasant, it was considered a natural and thus tolerable city sound: "Sounds of the city, which never end, it's sort of normal, it belongs to that life" (Woman B, 68). Those who had lived in the city for a long time observed that the centre had also become quieter after the introduction of car restrictions. Nowadays, the shopping environment resonates with music and international voices. More outdoor events for all ages were desired, but criteria for street musicians' playing skill were demanded.

\subsubsection{Cleanliness}

Uncleanliness evoked frustration; it was described that: "[Uncleanliness is] the greatest problem in the city centre, which is attractive otherwise" (Man, 73). The paper wrappings and cigarette butts on the pavement were the most annoying, in the Market Place surroundings in particular. The parking-hall development project was supported, not in terms of expanding the parking facilities, but as potentially cleaning up the Market Place. A cue should be taken from the Riverfront, where there has been investment in decorated bins, for example. The main problem, however, was perceived to lie in the attitudes of people: "There are too few rubbish bins...but the fault is also in the residents because they throw butts just where they're standing. No one can do anything unless people change their attitudes" (Woman, 79). The imposition of fines for littering was suggested.

\subsubsection{Lighting}

Given the seasonal variations in daylight (6 to 19 hours), lighting was highly emphasised. It was connected to convenience and safety, as well as colours and décor. It was described that white-coloured decorative lights reflected on facades and trees also illuminate the streets, and thus enhance convenience and feelings of security. It was also generally thought that the retailers' illuminated signs and display windows created a pleasant shopping environment, especially during the Christmas period. In public areas, the festive lights were perceived as modest. For the year-round festive illumination, provided that it is neither flashing nor multi-coloured, it was suggested that: "There should be other than Christmas lights...it'd liven up the attraction" (Woman, 71). However, it was highly emphasised that aesthetics should follow functionality in public lighting: "It's vital that there's good lighting so that older people can move around there" (Woman, 80).

\section{Discussion}

This study attested to the importance of the city centre for older shoppers (e.g., Wrigley \& Lambiri, 2015). It 
contributed to current knowledge by focusing on older consumers' perceptions of the elements in the external shopping environment (see Figure 1), which have not gained much attention in retailing (e.g., Hart et al., 2013). The focus-group discussions of 22 participants proved to be an appropriate method to identify what kinds of elements constitute an attractive city-centre shopping environment to older consumers, and how they do so. The elements, which evoked strong sensations, typically unattractive, raised proposals for improvements. The suggested means to develop the city centre should be actualized in order to make for a more age-friendly shopping environment. In addition, the study improved the current understanding of older consumers' shopping behaviour in the city centre.

The focus groups consisted of consumers aged 64+ who lived an active and independent life and wished to do so as long as possible. They confirmed that the versatile services, also targeted for older consumers, and the physical characteristics of the shopping environment were the assets of the age-friendly city centre (e.g., Buffel et al., 2012; Teller et al., 2016). As noticed in previous studies on older consumers (e.g., Kohijoki \& Marjanen, 2013), most of the focus-group participants were inclined towards recreational shopping. While shopping in the city centre, they were keen to spend time frequenting cafes and restaurants, meeting people, and sightseeing. This indicates that city shopping more than fulfilled the senior shoppers' consumption needs: it gave them a reason to go out, get some fresh air, and maintain social contacts. This was not offered in e-stores or out-of-town shopping centres.

Consistent with prior studies, the shopping environment that is functional with respect to layout, convenience, and safety proved to be essential for older consumers to cope with their shopping in the city centre (cf. De Nisco \& Warnaby, 2013; Hovbrandt et al., 2007). Focus groups reflected that barrier-free building-design regulations had enhanced convenience and safety in the transitional zone. Only in some historical buildings, the storefronts still require investment with regards to accessibility, such as installing handrails on stairs. The element which truly decreased functionality was the safety risk for older city shoppers of falling over/slipping on the pavement.

The availability and cost of parking have been found to be the key issues for city shoppers of all ages (e.g., Wrigley \& Lambiri, 2015). This study revealed that not all available car parks are convenient for older drivers. This refers to inaccessible parking halls and short-time parking that prevents lingering in the centre. It should be noted that a private car is a vital means for some seniors to run their errands. Thus, there should be spacious "family-parking" places made available to older shoppers at street level. Low-priced off-peak parking at around midday would benefit all city shoppers. However, an increasing number of non-driving seniors should not be forgotten for whom convenient public transportation access to the city centre is vital for coping with shopping.
Similar to previous findings (e.g., De Nisco \& Warnaby, 2013; Reimers \& Clulow, 2014), the environmental aesthetics were considered important, particularly among recreational focus-group participants who were attracted by the authentic city architecture and appealing details. Given that older consumers preferred bricks-and-mortar shopping to "screen shopping", wellmaintained and harmonious facades with illuminated advertising and well-designed window displays were considered pleasant. It is also noteworthy that the city parks and street plantings were seen as a vital part of an agefriendly shopping environment. Walking outdoors has been found to increase physical and mental well-being (see Hunter et al., 2011), so urban nature should be respected in the city centre. This study also showed that trees, flowers, artworks, and other décors of streetscape offer the means to harmonise the contrast between new and old architecture at a rather low cost. Investing in aesthetics is worthwhile as it may also enhance functionality. It was prioritised that smooth surfacing increases convenience and safety to move around whereas seating, both in public and private areas, allows senior shoppers to rest their feet and enjoy the cityscape.

The study confirmed that ambience influences shopping enjoyment (cf. Dellaert et al., 2008; Hart et al., 2013; Teller \& Reutterer, 2008), and can be crucial for older consumers to run errands outdoors. In spite of the Nordic climate, the city centre was attractive to older consumers all year round. Having fresh air was one of the upsides of city shopping. The traffic-born elements were tolerable in the car-restricted areas. To improve the year-round ambience, investment in pedestrian street maintenance, including waste management and lighting, was considered to be first in priority. Good outdoor lighting is vital for ageing eyes trying to cope with shopping. Efficient lighting increased shopping enjoyment by creating a functional and aesthetic environment. Lighting, even if decorative, is a fairly easy and low-price solution (e.g., floodlit buildings) to enliven the urban landscape.

The focus groups offered contents and meanings to the external elements, the effects of which on consumers have mostly been studied quantitatively. The discussions did not reveal new elements to the framework (Figure 1). The strengths of the study were that all the elements in the framework were discussed from the viewpoint of the highly-involved consumers, and in one city centre. The elements which evoked the most vivid discussion among the participants were convenience, safety, architecture, furnishings, lighting, and cleanliness. Although the elements were discussed one by one, the summaries of the contents reflect that the design and ambient elements were related to each other, having a synergetic influence on attractiveness. Convenience was related to several aesthetic (e.g., furnishing, material) and ambient (e.g., weather, lighting) elements. The architecture was closely connected to other aesthetic elements, and ambient lighting had both functional (e.g., convenience and safety) and aesthetic connotations (e.g., colours and 
decors). This synergy effect should be taken into account when developing the city-centre shopping environment.

To identify what kind of elements constitute an attractive city-centre shopping environment, and how they do so, the study focused both on the pleasant and unpleasant perceptions. It can be summarised that the unattractive shopping environment was constructed based on a dull and inconsistent architectural style, inconvenient and unsafe cobblestone (or other uneven) street surfacing, the lack of proper seating and lighting, and untidiness of the streetscape. The attractiveness of the shopping environment was attributed to the consistent architectural style with warm-coloured, spot-lit and decorated buildings, the uniformly surfaced and illuminated pavements, proper seating both in public and private areas, artworks, elements of nature, and decorated rubbish bins along the streets.

In the case of Turku, these attributes can be contextualised to the Market Place and the Riverfront (Figures 3 and 4), which were in different phases of the revitalisation process. The centrally located Market Place received full marks for being a vital service environment for older consumers, but it was considered a non-functional and anaesthetic shopping environment. To develop the environment in a more age-friendly manner, cue should be taken from the Riverfront, where investment has paid off, in light of the positive perceptions and actions of older city shoppers. However, the study showed that, from an older consumer's perspective, in order to revitalise the Market Place, or any other external shopping environment, the actions do not need to be large-scale. Even the minutiae (e.g., lights, chairs, flowers, etc.) have a notable effect; they are usually easy to control and incur quite low costs. It was also shown that the bricks-andmortar entrepreneurs have a strong influence in the transitional zone. However, influencing city-centre attractiveness at the large scale requires co-operation among several actors.

\section{Limitations and Future Research}

The study was limited to the medium-sized city located in Northern Europe. Thus, the findings are best applicable to cities with similar demographic characteristics and seasonal climatic variations. However, the fundamental challenges related to consumer ageing that face urban and retail planners are similar irrespective of the location and size of the city. A comparative study between several cities is suggested to confirm this statement. In addition, as the findings reflected woman-dominated perceptions, to compare the genders in the further studies, a different strategy should be considered when recruiting male volunteers. Although the study focused only on older consumers, it is worth noticing that meeting the needs of older city shoppers does not have to be at the expense of younger ones. Consumers may be mobility-restricted in different phases of their lives, for example, and for several reasons. To develop city centres that are friendly for all ages, comparative research using the framework of the study is suggested. As the study has reached its goals methodologically, the focus-group approach is recommended for these comparative studies. To continue with this topic among older consumers, walking-along interviews, for example, could reveal how the elements affect consumers when shopping in the city centre. Finally, the study focused on tangibles, as they offer concrete means to enhance the shopping environment. In the focus-group discussions, social aspects also emerged, reflecting that the city centre offers a social living-room setting to older shoppers. Given that older consumers in the Western cities are increasingly living alone, there is a need for research on the role of shopping in fulfilling social needs and preventing loneliness. It is essential to develop the built environment, service provision, and social aspects in city centres to make them more age-friendly.

\section{Acknowledgments}

This work was supported by the City of Turku and The Foundation for Economic Education. The authors offer their warm thanks to the persons responsible for helping to organise the discussions, and especially to the consumers who participated in the discussions with an open mind.

\section{Conflict of Interests}

The authors declare no conflict of interest.

\section{References}

Baker, J. (1986). The role of environment in marketing services: The consumer perspective. In J. A. Czepiel, C. A. Congram, \& J. Shanaham (Eds.), The service challenge: Integrating for competitive advantage ( $\mathrm{pp}$. 79-84). Chicago, IL: American Marketing Association.

Baker, J., Grewal, D., \& Parasuraman, A. (1994). The influence of store environment on quality inferences and store image. Journal of the Academy of Marketing Science, 22(4), 328-339. https://doi.org/10. $1177 / 0092070394224002$

Bell, S. J. (1999). Image and consumer attraction to intraurban retail areas: An environmental psychology approach. Journal of Retailing and Consumer Services, 6(2), 67-78. https://doi.org/10.1016/509696989(98)00015-0

Bitner, M. J. (1992). Servicescapes: The impact of physical surroundings on customers and employees. Journal of Marketing, 56(2), 57-71. https://doi.org/10.2307/ 1252042

Bromley, R. D. F., \& Thomas, C. T. (2002). Food shopping and town centre vitality: Exploring the link. The International Review of Retail, Distribution and Consumer Research, 12(2), 109-130. https://doi.org/10.1080/ 09593960210127682

Buffel, T., Phillipson, C., \& Scharf, T. (2012). Ageing in 
urban environments: Developing 'age-friendly' cities. Critical Social Policy, 32(4), 597-617. https://doi.org/ $10.1177 / 0261018311430457$

City of Turku. (2014). Turku 2029 city strategy. The City of Turku. Retrieved from www.turku.fi/sites/default/ files/atoms/files//kaupunkistrategia2029_weben.pdf

Dawson, S., Bloch, P. H., \& Ridgway, N. M. (1990). Shopping motives, emotional states, and retail outcomes. Journal of Retailing, 66(4), 408-427.

De Nisco, A., \& Warnaby, G. (2013). Shopping in downtown. The effect of urban environment on service quality perception and behavioural intentions. International Journal of Retail \& Distribution Management, 41(9), 654-670. https://doi.org/10.1108/ IJRDM-05-2013-0106

De Nisco, A., \& Warnaby, G. (2014). Urban design and tenant variety influences on consumers' emotions and approach behaviour. Journal of Business Research, 67(2), 211-217. https://doi.org/10.1016/ j.jbusres.2012.10.002

Dellaert, B. G. C., Arentze, T. A., \& Timmermans, H. J. P. (2008). Shopping context and consumers' mental representation of complex shopping trip decision problems. Journal of Retailing, 84(2), 219-232. https:// doi.org/10.1016/j.jretai.2008.02.001

Donovan, R. J., \& Rossiter, J. R. (1982). Store atmosphere: An environmental psychology approach. Journal of Retailing, 58(1), 34-57.

Ethics Committee of the University of Turku. (2018). The preliminary assessment of non-medical research. University of Turku. Retrieved from www.utu.fi/en/ research/ethicality/assessment-of-non-medicalresearch/Pages/home.aspx

Eurostat Database. (2018). Projected old-age dependency ratio. EC Europa. Retrieved from https://ec. europa.eu/eurostat/web/products-datasets//tsdde511

Hart, C., Stachow, G., \& Cadogan, J. W. (2013). Conceptualising town centre image and the customer experience. Journal of Marketing Management, 29(15/16), 1753-1781. https://doi.org/10.1080/ $0267257 X .2013 .800900$

Hovbrandt, P., Ståhl, A., Iwarsson, S., Horstmann, V., \& Carlsson, G. (2007). Very old people's use of the pedestrian environment: Functional limitations, frequency of activity and environmental demands. European Journal of Ageing, 4, 201-211. https://doi.org/ 10.1007/s10433-007-0064-2

Hunter, R. H., Sykes, K., Lowman, S. G., Duncan, R., Satariano, W. A., \& Belza, B. (2011). Environmental and policy change to support healthy aging. Journal of Aging \& Social Policy, 23(4), 354-371. https://doi.org/ 10.1080/08959420.2011.605642

Kitzinger, J. (1995). Qualitative research: Introducing focus groups. BMJ, 311(7000), 299-302. https://doi. org/10.1136/bmj.311.7000.299

Kohijoki, A.-M. (2011). The effect of aging on consumer disadvantage in grocery retail services among the
Finnish elderly. Journal of Retailing and Consumer Services, 18(4), 370-377. https://doi.org/10.1016/j. jretconser.2011.04.003

Kohijoki, A.-M., \& Koistinen, K. (2018). The effect of the physical environment on consumers' perceptions: A review of the retailing research on external shopping environment. Architecture and Urban Planning, 14, 83-90. https://doi.org/10.2478/aup-2018-0011

Kohijoki, A.-M., \& Marjanen, H. (2013). The effect of age on shopping orientation: Choice orientation types of the ageing shoppers. Journal of Retailing and Consumer Services, 20(4), 165-172. https://doi.org/10. 1016/j.jretconser.2012.11.004

Krueger, R. A. (1988). Focus groups. A practical guide for applied research. Riverside County, CA: Sage Publications.

Laukkanen, M. (2016). Tulevaisuuden Turku 2029 [Findings of the future Turku 2029 survey]. City of Turku. Retrieved from www.turku.fi/sites/default/files/ atoms/files//kyselyraportti.pdf

Maronick, T. J. (2007). Specialty retail center's impact on downtown shopping, dining, and entertainment. International Journal of Retail \& Distribution Management, 35(7), 556-568. https://doi.org/10.1108/ 09590550710755930

Mayring, P. (2004). Qualitative content analysis. In U. Flick, E. von Kardorff, \& I. Steinke. (Eds.), A companion to qualitative research (pp. 266-269). London: Sage Publications.

Morgan, D. L. (1997). Focus groups as qualitative research. Thousand Oaks, CA: Sage Publications.

Myers, H., \& Lumbers, M. (2008). Understanding older shoppers: A phenomenological investigation. Journal of Consumer Marketing, 2(5), 294-301. https://doi. org/10.1108/07363760810890525

Official Statistics of Finland. (2018). StatFin statistical database. Statistics of Finland. Retrieved from www. stat.fi/til/index_en.html

Parker, C., Ntounis, N., Millington, S., Quin, S., \& CastilloVillar, C. F. (2017). Improving the vitality and viability of the UK high street by 2020: Identifying priorities and a framework for action. Journal of Place Management and Development, 10(4), 310-348. https:// doi.org/10.1108/JPMD-03-2017-0032

Reimers, V., \& Clulow, V. (2014). Spatial convenience: Bridging the gap between shopping malls and shopping strips. International Journal of Retail \& Distribution Management, 42(10), 864-883. https://doi.org/ 10.1108/IJRDM-08-2013-0153

Rosenbaum, M., \& Massiah, C. (2011). An expanded servicescape perspective. Journal of Service Marketing, 22(4), 471-490. https://doi.org/10.1108/ 09564231111155088

Teller, C. (2008). Shopping streets versus shopping malls: Determinants of agglomeration format attractiveness from the consumers' point of view. International Review of Retail, Distribution and Consumer Research, 18(3), 381-403. http://dx.doi.org/10.1080/ 
09593960802299452

Teller, C., \& Reutterer, T. (2008). The evolving concept of retail attractiveness: What makes retail agglomerations attractive when customers shop at them? Journal of Retailing and Consumer Services, 15(3), 127-143. https://doi.org/10.1016/j.jretconser.2007. 03.003

Teller, C., Wood, S., \& Floh, A. (2016). Adaptive resilience and the competition between retail and service agglomeration formats: An international perspective. Journal of Marketing Management, 32(17/18), 1537-1561. https://doi.org/10.1080/ $0267257 X .2016 .1240705$

Tuomi, J., \& Sarajärvi, A. (2018). Laadullinen tutkimus ja sisällönanalyysi [Qualitative research and content analysis]. Helsinki: Kustannusosakeyhtiö Tammi.

Turley, L. W., \& Milliman, R. E. (2000). Atmospheric effects on shopping behavior: A review of the experimental evidence. Journal of Business Research, 49, 193-211. https://doi.org/10.1016/S01482963(99)00010-7

Underhill, P. (1999). Why we buy: The science of shopping. New York, NY: Touchstone.

Wrigley, N., \& Lambiri, D. (2015). British high streets: From crisis to recovery? A comprehensive review of the evidence. Southampton: University of Southampton, Economic \& Social Research Council.

\section{About the Authors}

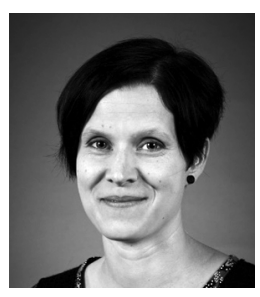

Anna-Maija Kohijoki received the degree of Doctor of Science in Economics (Economic Geography) in 2013 from the Turku School of Economics, University of Turku. The focus of her doctoral thesis was the physical and experienced accessibility of grocery retail services with special reference to ageing consumers. Currently, she is working as a university teacher in economic geography at the Turku School of Economics. Her research interests include consumer spatial behaviour, urban planning, and applications of GIS in business.

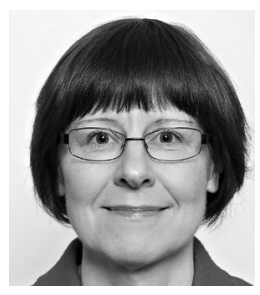

Katri Koistinen received the degree of Doctor of Philosophy (Economic Geography) in 2006 from the Turku School of Economics, University of Turku. Her doctoral thesis focused on the planning and decision-making process that led to the decision to locate Mylly, the biggest shopping centre in SouthWest Finland, in Hauninen area in Raisio. Koistinen works as a university lecturer at the Centre for Consumer Society Research at the University of Helsinki. Her research interests are the geography of retailing, services, consumer behaviour, urban planning, and qualitative methods. 